\title{
Detection of Apoptotic DNA Ladder in Pig Leukocytes and its Precision Using LM-PCR (Ligation Mediated Polymerase Chain Reaction)
}

\author{
E. MATALOVÁ ${ }^{1}$, A. ŠPANOVÁ ${ }^{2}$ \\ ${ }^{1}$ Institute of Animal Physiology and Genetics, Academy of Sciences, Brno, Czech Republic \\ 2 Department of Microbiology, Faculty of Science, Masaryk University, Brno, Czech Republic \\ Received October 31, 2001 \\ Accepted June 19, 2002
}

Abstract

Matalová E., A. Španová: Detection of Apoptotic DNA Ladder in Pig Leukocytes and its Precision Using LM-PCR (ligation mediated polymerase chain reaction). Acta Vet. Brno 2002, 71: $163-168$.

Apoptosis as a way of programmed cell death represents an extremely important phenomenon in development and everyday maintenance of homeostasis in multicellular organisms. Regarding the keen interest in programmed cell death in the last ten years, more and more assays and kits are emerging to prove apoptosis. However, their detectability and reliability have been often discussed.

Apoptotic DNA changes in pig leukocytes as a consequence of phagocytosis were investigated by two methods available for qualitative apoptosis evaluation in cell populations. Traditionally used and quick screening of apoptotic DNA fragmentation by agarose gel electrophoresis showed negative results or a non-typical apoptotic ladder. The new approach using LM-PCR technique was tested to make those results more precise and to find out if a typical DNA ladder can be obtained. Apoptotic cells were quantified using TUNEL test.

LM-PCR technique has been shown not only as a method for result precision in the case of negative findings by DNA ladder assay but also as an effective assay in case of non-typical apoptotic DNA ladder appearance. Moreover, LM-PCR detected an apoptotic ladder even in populations with less than $1 \%$ of apoptotic cells.

Apoptosis, phagocytosis, DNA ladder

Apoptosis (Kerr et al. 1972) represents an organized, energy-dependent process leading to cell death. This mode of cell death is physiological, genetically controlled and is of fundamental importance to tissue development and homeostasis. Cellular susceptibility to apoptosis is determined by a variety of signals, of both extracellular and intracellular origin, including proliferative status. Because of necessity of this process in everyday maintenance of multicellular organisms and its relevance to many disorders, this topic interferes with numerous fields in molecular and cellular biology as well as in experimental and clinical medicine. Due to specific pathways and control of apoptotic events, many possibilities to modulate this process are open.

During apoptotic cell death, cellular endonucleases cleave genomic DNA between nucleosomes (Wyllie 1980; Arends et al. 1990; Enari et al. 1998; Saraste 1999), producing fragments whose lengths vary by multiples of 180-200 bp. When resolved using agarose gel electrophoresis, these DNA fragments appear as a nucleosomal ladder, a widely recognized hallmark of apoptosis (Aaij et B orst 1972; Compton 1992; Hale et al. 1996). For quick screening of apoptosis in biological systems in which only a small percentage of cells underwent apoptosis or the apoptotic process occurs asynchronously, DNA ladder may not be visible or only as a smear. The LM-PCR assay (Staley et al. 1997) uses the polymerase chain reaction to specifically amplify the nucleosomal ladder, making it easier to detect.

In this article we report on sample preparation and exploitation of traditional detection of specific DNA ladder pattern after agarose gel electrophoresis compared with its precision

Address for correspondence:

Eva Matalová

Academy of Sciences, Inst. of Animal Physiology and Genetics

Czech Republic (Europe)
Phone: +420-5-41562205

Fax: +420-5-49211482

http://www.vfu.cz/acta-vet/actavet.htm 
using LM-PCR for proving apoptosis in cell populations. Pig leukocytes undergoing apoptosis as a consequence of phagocytosis were tested to compare results obtained by using mentioned methods for apoptotic DNA fragmentation detection. Quantification of apoptotic cells and verification of apoptotic events at individual cell level were proceeded by TUNEL AP test.

\section{Materials and Methods}

Samples

Leukocytes from 6-week-old piglets were used in this study. Blood samples $(20 \mathrm{ml})$ were taken from 12 healthy animals (Duroc breed, 6 females, 6 males, Agriculture Farm, Nové Dvory, Czech Republic) and stabilized with heparin (12 i. u./ml).

Experimental design

Blood samples were divided into four groups and mixed with living and killed bacteria, and with microspheric particles, respectively ( $1 \mathrm{ml}$ of blood $+0.1 \mathrm{ml}$ of bacteria or particles in PBS), and incubated at $37^{\circ} \mathrm{C}$.

The experiment was started with addition of bacterial cells (living or killed) and MSHP (control of phagocytosis) and PBS alone, respectively, to the blood samples. At given intervals $(1,4,8,12,24,48 \mathrm{~h}$ after start of the experiment), samples were taken for DNA analysis and in 1,2 and $3 \mathrm{~h}$ for bactericidal capacity evaluation. To avoid bacterial cell division during prolonged cultivation, ampicillin $(100 \mu \mathrm{g} / \mathrm{ml})$ was added to all samples.

Salmonella typhimurium LB 5000 ( Bullas et Ryu 1983) bacterial cells were used in this study. One colony of the bacterial strain was grown overnight in LB medium ( $10 \mathrm{~g}$ Bacto tryptone, $5 \mathrm{~g}$ Bacto yeast extract, $5 \mathrm{~g} \mathrm{NaCl}$ in $1000 \mathrm{ml} \mathrm{H}_{2} \mathrm{O}$ ) and then washed twice in PBS buffer (phosphate-buffer saline: $100 \mathrm{~g} \mathrm{NaCl}, 2.5 \mathrm{~g} \mathrm{KCl}, 14.4 \mathrm{~g}$ $\mathrm{Na}_{2} \mathrm{HPO}_{4}, 2.5 \mathrm{~g} \mathrm{KH}_{2} \mathrm{PO}_{4}$ in $1000 \mathrm{ml} \mathrm{H} 2 \mathrm{O}$ ). The final density of the cells was $1 \times 10^{9} \mathrm{cfu} / \mathrm{ml} \mathrm{PBS}$. A suspension with killed bacteria was obtained after heating the cell culture in LB medium $30 \mathrm{~min}$ at $72{ }^{\circ} \mathrm{C}$ and then washed twice in PBS buffer.

Sample preparation

Sufficient number of cells $\left(10^{7}\right)$ was washed in PBS (phosphate-buffer saline, $\mathrm{pH}$ 7.4: $137 \mathrm{mM} \mathrm{NaCl}, 2.7 \mathrm{mM}$ $\mathrm{KCl}, 1.5 \mathrm{mM} \mathrm{KH}_{2} \mathrm{PO}_{4}, 8.1 \mathrm{mM} \mathrm{Na} \mathrm{HPO}_{4}$ in distilled water) and resuspended in $1 \mathrm{ml}$ of lysis buffer (50mM Tris $\mathrm{pH}=8,10 \mathrm{mM} \mathrm{NaCl}, 100 \mathrm{mM}$ EDTA $\mathrm{pH}=8,1 \% \mathrm{SDS}, 100 \mathrm{~g}$ proteinase $\mathrm{K}$ in $1 \mathrm{ml} \mathrm{H}_{2} \mathrm{O}$ ). During lysis, samples were kept at $37^{\circ} \mathrm{C}$ for $1 \mathrm{~h}$. The lysates were stored at $4{ }^{\circ} \mathrm{C}$ until gel electrophoresis.

DNA purification

Samples were deproteined twice with distilled phenol, and the water phase separated. Then 1:1 CIZ (chloroform : isoamylalcohol $=24: 1$ ) was added, carefully mixed, spun af $12000 \mathrm{~g} / 5 \mathrm{~min} / 4{ }^{\circ} \mathrm{C}$ and the water with DNA separated. The achieved DNA purity $\left(\mathrm{A}_{260} / \mathrm{A}_{280}=1.8-1.9\right)$ was confirmed by spectrophotometry (DMS-100S Varian Techtron, Mulgrowe, Australia).

\section{LM-PCR}

(ligation-mediated polymerase chain reaction) (Staley et al. 1997)

This method was proceeded with purified DNA following producer's manual (ClonTech, USA distributed by SpinChem, Czech Republic). After ligation of adaptors to apoptotic DNA breaks, DNA fragments were multiplied in PCR cycles. Ligation reactions were incubated over night $\left(16 \mathrm{~h} / 16^{\circ} \mathrm{C}\right) .100 \mathrm{ng}$ of adaptor-ligated DNA was added to PCR mixture and 35 cycles were performed in MJ Research PTC- 100 cycler: $72{ }^{\circ} \mathrm{C} / 8 \mathrm{~min},\left(94^{\circ} \mathrm{C} / 1 \mathrm{~min}\right.$, $72{ }^{\circ} \mathrm{C} / 3 \mathrm{~min}$ ) $/ 35 \mathrm{x}, 72{ }^{\circ} \mathrm{C} / 15 \mathrm{~min}$. Advantage cDNA Polymerase Mix (SpinChem, Czech Republic) with TaqStart antibody was used.

\section{DNA Ladder Assay}

Loading buffer $\left(0.4\right.$ bromphenol blue, $25 \mathrm{~g}$ Ficoll 400 in $\left.1000 \mathrm{ml} \mathrm{H}_{2} \mathrm{O}\right)(9 \mu \mathrm{l})$ was added to each sample $(45 \mu \mathrm{l})$ and this mixture applied on $1.8 \%$ agarose gel, into one run DNA marker resuspended in distilled water was added with the loading buffer. Neutral gel electrophoresis $(1.8 \%$ agarose, $3 \mathrm{~V} / \mathrm{cm})$ was proceeded in TBE buffer $(5.4 \mathrm{~g}$ Tris base, $2.75 \mathrm{~g}$ boric acid, $0.5 \mathrm{M}$ EDTA pH=8 in $1000 \mathrm{ml} \mathrm{H}_{2} \mathrm{O}$ ), then the gel was stained with ethidiumbromide $(1 \mu \mathrm{g} / \mathrm{ml})$ - water bath.

\section{TUNEL AP test}

Terminal deoxynucleotidyl transferase mediated dUTP nick end labelling (Gavrieli et al. 1992) was exploited to confirm apoptotic DNA fragmentation and to quantify apoptotic changes in individual cells. Samples were fixed in 4\% paraformaldehyde and the labelling reaction was proceeded according producer's directions (Roche Chemicals, Germany). After conversion using substrate for alkaline phosphatase (Fast Red, Sigma Aldrich, USA) cells were counted under light microscopy. 


\section{Results}

In this experiment, application of LM-PCR method for precision of apoptotic DNA ladder detection using agarose gel electrophoresis, was tested. Apoptosis was evoked as a consequence of phagocytosis of microspheric particles, living and killed bacterial cells, respectively (Matalová et al. 2000). Six-week-old animals were chosen to test the LMPCR improvement, because non-typical apoptotic ladder was observed in these samples although enough of these cells were TUNEL positive. The percentage of apoptotic cells detected by TUNEL AP in three time intervals after phagocytosis is shown in Table 1.

Table 1

Percentage of apoptotic cells in total leukocytes detected using TUNEL AP test

\begin{tabular}{|c|c|c|c|}
\hline Sample & Average & Average error & Standard deviation \\
\hline P & 0.3 & 0.25 & 0.71 \\
\hline A1 & 0.5 & 0.27 & 0.76 \\
\hline B1 & 0.6 & 0.38 & 1.06 \\
\hline C1 & 0.1 & 0.13 & 0.35 \\
\hline D1 & 0.5 & 0.27 & 0.76 \\
\hline A4 & 0.8 & 0.41 & 1.17 \\
\hline B4 & 7.9 & 0.41 & 1.16 \\
\hline C4 & 8.2 & 0.62 & 1.75 \\
\hline D4 & 6.0 & 0.27 & 0.75 \\
\hline A8 & 8.8 & 0.45 & 1.27 \\
\hline B8 & 14.1 & 0.45 & 1.28 \\
\hline C8 & 13.7 & 0.41 & 1.70 \\
\hline D8 & 12.7 & 0.60 & \\
\hline
\end{tabular}

P ... control prior to start of experiment

A ... control without phagocytosis

B ... samples cultivated with MSH particles

C ... samples cultivated with killed bacteria

D ... samples cultivated with living bacteria

Results obtained using common ladder assay and LM-PCR in three time intervals after phagocytosis were compared (see Plate VII, Figs. 1,2) and estimated regards to number of apoptotic cells detected by TUNEL assay (Table 2).

As demonstrated in Fig. 1 the optimal amount of ligated - DNA into PCR mixure was tested (according producer's directions between 50 and $150 \mathrm{ng}$ ) and also the number of PCR cycles (shown results for 30 and 35 cycles).

In the control prior to experiment, no DNA fragmentation was detected and when quantified by TUNEL less than $1 \%$ of apoptotic leukocytes was found. In the control group without phagocytosis no DNA fragmentation was proved in all three intervals by DNA ladder assay whereas in phagocyting leukocytes discrete DNA fragments were found $8 \mathrm{~h}$ after phagocytosis in all samples (Fig. 2). As indicated in Plate VIII, Fig. 3 after 35 PCR cycles using adaptor-ligated DNA, fragmentation of DNA was observed in phagocyting leukocytes after $1 \mathrm{~h}$ (runs 2-4) already and the typical ladder was proved after $8 \mathrm{~h}$ (runs 68). In the control group, the DNA was intact (runs 1, 5, 9) during the experiment.

Findings obtained by DNA gel electrophoresis and LM-PCR, respectively, were confronted with number of apoptotic cells detected by TUNEL AP. As indicated in Table 2, the LM-PCR technique was able to prove DNA fragmentation also in cell populations where the percentage of apoptotic cells was less than 1\%. Moreover, the LM-PCR method proved the typical apoptotic ladder in samples where the common DNA electrophoresis enabled only detection of longer discrete fragments. 
Table 2

Comparison of results obtained using DNA ladder assay and LM-PCR, respectively, in regard to percentage of apoptotic cell evaluated by TUNEL AP

\begin{tabular}{|c|c|c|c|}
\hline Sample & \% of apoptotic cells & DNA ladder assay & LM-PCR \\
\hline A1 & 0.5 & - & - \\
\hline B1 & 0.6 & - & + \\
\hline C1 & 0.1 & - & + \\
\hline D1 & 0.5 & - & - \\
\hline A4 & 0.8 & - & + \\
\hline B4 & 7.9 & $+\mathrm{a}$ & + \\
\hline C4 & 8.2 & $+\mathrm{a}$ & + \\
\hline D4 & 6.0 & $+\mathrm{a}$ & + \\
\hline A8 & 8.8 & + & + \\
\hline B8 & 14.1 & + & + \\
\hline C8 & 13.3 & + & + \\
\hline D8 & 12.7 & + & + \\
\hline
\end{tabular}

A ... control without phagocytosis

B ... samples cultivated with MSH particles

C ... samples cultivated with killed bacteria

D ... samples cultivated with living bacteria

$+n$... DNA fragmentation with non typical apoptotic

ladder pattern

$+\ldots$ DNA fragmentation with typical apoptotic ladder pattern

$1 \ldots 1 \mathrm{~h}$ after phagocytosis beginning

$4 \ldots 4 \mathrm{~h}$ after phagocytosis beginning

$8 \ldots 8 \mathrm{~h}$ after phagocytosis beginning

$-\ldots$ no DNA fragmentation detected

\section{Discussion}

The definition of apoptosis is still based on two hallmarks of the process: distinct morphological features and internucleosomal DNA degradation resulted into so-called apoptotic ladder of DNA fragments detectable on agarose gel after neutral electrophoresis. However, it has been reported that in liver tissue undergoing ischemic necrosis without morphological evidence of apoptosis a distinct DNA ladder pattern can be developed (Fukuda et al. 1993), whereas, morphologically proved apoptosis is not always associated with formation of DNA ladder (Oberhammer et al. 1993; Corcoran et al. 1994; Schulze-Osthoff et al. 1994). Therefore DNA fragmentation pattern (so called DNA ladder) should not be used as the only apoptosis indication (Collin s et al. 1992). Moreover, the detectability of DNA ladder assay can be decreased also in samples where the number of apoptotic cells is lower than about 5\%. In these cases, but as well as when non typical DNA fragments were detected, the LM-PCR method allowed to verify apoptotic cleavage. During the apoptotic process genomic DNA is cleaved in more consequent steps. First cleavage into fragments with length $300 \mathrm{kbp}$ is followed by additional fragmentation into 50 $\mathrm{kbp}$ and thereafter to oligonucleosomal DNA fragments (Oberhammer et al. 1993). Our results support this fact as after LM-PCR multiplication of DNA fragments also short bands in the typical ladder pattern were identified. To quantify apoptosis in leukocytes the TUNEL test was used and the number of detected apoptotic cells compared with findings obtained by using DNA ladder assay and LM-PCR, respectively.

DNA ladder assay is an easily available method and seems to be very useful for quick screening of apoptotic changes in cell populations. This method allows working with cell lysates and does not request any special laboratory equipment. However, its sensitivity is limited. This disadvantage can be solved by applying of LM-PCR method. In summary, LMPCR enables detection of apoptotic DNA cleavage pattern with higher sensitivity than common DNA ladder assay, the multiplied apoptotic fragments give also higher quality for documentation. Moreover, the LM-PCR represents a semiquantitative technique, where 
known amount of DNA added into PCR mixture and number of PCR cycles allow estimation and relative comparison of DNA fragmentation extent in investigated samples. Whereas, the LM-PCR method requests purified DNA, precise work, PCR equipment and thus is much more time consuming than commonly used agarose gel electrophoresis.

In this work the LM-PCR technique has been shown not only as a method for result precision in the case of negative findings by DNA ladder assay but also in case of non-typical apoptotic DNA ladder appearance with effectiveness even in populations with less than $1 \%$ of apoptotic cells.

\section{Detekce apoptotických fragmentů DNA v prasečích leukocytech a její zpřesnění $s$ využitím LM-PCR (ligation-mediated polymerase chain reaction)}

Apoptóza jako jedna z cest programované buněčné smrti představuje důležitý fenomén při vývoji a každodenním udržování homeostáze mnohobuněčných organismů. Vzhledem ke vzrůstajícímu zájmu o problematiku programované buněčné smrti v posledním desetiletí se objevuje stále více postupů a detekčních souprav pro průkaz apoptózy. Nicméně, jejich přesnost a spolehlivost bývá často diskutována.

Dvě metody používané pro kvalitativní hodnocení apoptotických změn DNA v buněčných populacích byly testovány u prasečích leukocytů podstupujících apoptózu vyvolanou fagocytózou. Tradičně užívaný průkaz apoptotického DNA žebříčku po agarózové gelové elektroforéze ukázal pouze netypický výsledek s dvěma DNA fragmenty. $S$ využitím nového postupu založeném na technice LM-PCR byla testována možnost zpřesnění získaných výsledků a také možnost průkazu klasického apoptotického DNA žebříčku pomocí této metody $\mathrm{v}$ případě netypické fragmentace detekované klasickým postupem. Kvantifikace apoptotických buněk byla prováděna TUNEL testem.

Technika LM-PCR je nejenom metodou umožňující zpřesnění výsledků po klasické agarózové elektroforéze, ale také možností průkazu typického žebříčku detekovatelného klasickým postupem pouze jako netypickou fragmentaci. Dále bylo prokázáno, že s využitím LM-PCR lze detekovat apoptotický žebříček u populací s méně než $1 \%$ apoptotických buněk.

\section{Acknowledgements}

This work has been supported in part by the Grant Agency of the Czech Republic (304/01/0850).

\section{References}

AAIJ, C, BORST, P 1972: The gel electrophoresis of DNA. Biochim Biophys Acta 269: 192-200

ARENDS, MJ, MORRIS, RG, WYLLIE, AH 1990: Apoptosis. The role of the endonuclease. Am J Pathol 136: 593-607

ARENDS, MJ, WYLLIE, AH 1991: Apoptosis: Mechanisms and roles in pathology. Int Rev Exp Pathol 32: 223-254

COLLINS, RJ, HARMON, BK, GOBE, GC, KERR, JFR 1992: Internucleosomal DNA cleavage should not be the sole criterion for identifying apoptosis. Int J Radiat Biol 61: 451-453

COMPTON, MM 1992: A biochemical hallmark of apoptosis: Internucleosomal degradation of the genome. Cancer Metast Rev 11: 105-119

COOPER, WA, DUARTE, IG, THOURANI, VH, NAKAMURA, M, WANG, NP, GOTT, JP, VINTENJOHANSEN, J, GUYTON, RA 2000: Hypothermic circulatory arrest causes multisystem vascular endothelial dysfunction and apoptosis. Ann Thorac Surg 69: 696-702

CORCORAN, GB, FIX, L, JONES, DP, MOSLEN, M, NICOTERA, P, OBERHAMMER, FA, BUTTYAN, R 1994: Apoptosis: Molecular control point of cytotoxicity. Toxicol Appl Pharmacol 128: 169-181

DIVE, C, GREGORY, CD, PHIPPS, DJ, EVANS, DL, MILNER, AE, WYLLIE, AH 1992: Analysis and discrimination of necrosis and apoptosis (programmed cell death) by multiparamether flow cytometry. Biochim Biophys Acta 11333: 275-285

ENARI, M, SAKAHIRA, H, YOKOYAMA, H 1998: A caspase-activated DNase that degrades DNA during apoptosis, and its inhibitor ICAD. Nature 391: 43-50

FUKUDA, K, KOJIRO, M, CHIU, JF 1993: Demonstration of extensive chromatin cleavage in transplanted Morris hepatoma 7777 tissue: Apoptosis or necrosis? Am J Pathol 142: 935-946 
GAVRIELI, Y, SHERMAN, Y, BEN SASSON, SA 1992: Identification of programmed cell death in situ via specific labeling of nuclear DNA fragmentation. J Cell Biol 119: 493-501

HALE, AJ, SMITH, CA, SUTHERLAND, LC, STONEMAN, VE, LONGTHORNE, V, CULHANE AC, WILLIAMS GT 1996: Apoptosis: molecular regulation of cell death. Eur J Biochem 237: 884

KERR, JFR, WYLLIE, AH, CURRIE, AR 1972: Apoptosis: a basic biological phenomenon with wide-ranging implication in tissue kinetics. Brit J Cancer 68: 239-257

MATALOVÁ, E, ŠPANOVÁ, A, KOVÁŘU゚, F, HEROLDOVÁ, M 2000: Apoptosis activation in pig leukocytes after phagocytosis of Salmonella typhimurium. Acta Vet Brno 69: 11-15

OBERHAMMER, F, WILSON, JW, DIVE, C, MORRIS, ID 1993: Apoptotic cell death in epithelial cells: cleavage of DNA to 300 and/or $50 \mathrm{~Kb}$ fragments prior or in absence of internucleosomal fragmentation. EMBO J 12: 3679-3684

SARASTE, A 1999: Morphologic criteria and detection of apoptosis. Herz 24: 189-195

SCHULZE-OSTHOFF, K, WALCZAK, H, DROGE, W, KRAMMER, PH 1994: Cell nucleus and DNA fragmentation are not required for apoptosis. J Cell Biol 127: 15-20

STALEY, K, BLASCHKE, AJ, CHUN, J 1997: Apoptotic DNA fragmentation is detected by a semiquantitative ligation-mediated PCR of blunt DNA ends. Cell Death Diff 4: 66-75

WYLLIE, A, KERR, JFR, CURRIE, AR 1980: Cell death: the significance of apoptosis. Int Rev Cytol 68: 251 306 
Plate VII

Matalová E., Španová A.: Detection... pp. 163-168

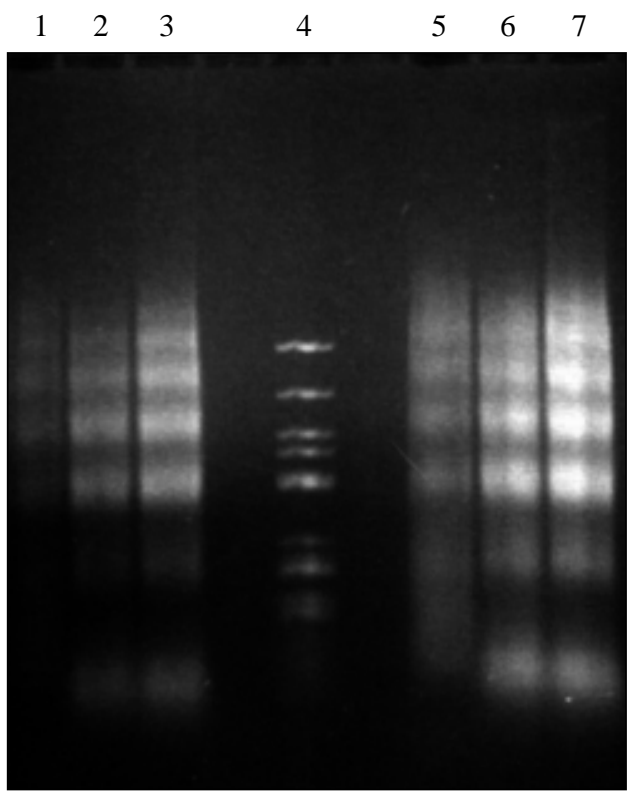

Fig. 1. Optimalization of amount of ligated-DNA into PCR mix and number of PCR cycles. Runs: 1-3/ 30 PCR cycles, 1 - $50 \mathrm{ng}, 2-100 \mathrm{ng}, 3$ - $150 \mathrm{ng}$ of ligated DNA into PCR mixture, 4 - DNA marker, 6-8/ 35 PCR cycles, 5 - $50 \mathrm{ng}, 6-100 \mathrm{ng}, 7-150 \mathrm{ng}$ of ligated DNA into PCR mixture

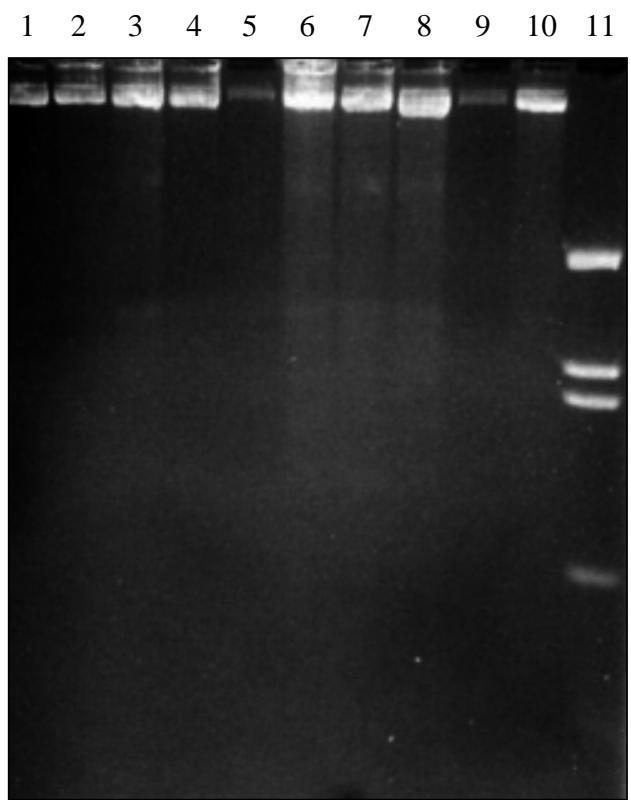

Fig. 2. DNA ladder assay: DNA fragmentation in leukocytes from four cultivated groups in given time intervals obtained by DNA ladder assay showing non-typical DNA ladder with two discrete fragments. Runs: 1-prior to experiment, 2- A/1h, 3-B/1h, 4-C/1h, 5-D/1h, 6-A/4h, 7-B/4h, 8-C/4h, 9-D/4h, 10-A/8h, 11-B/8h, 12-C/8h, 13-D/8h, 14-23: typical DNA ladder in later intervals, 24-DNA marker 
Plate VIII
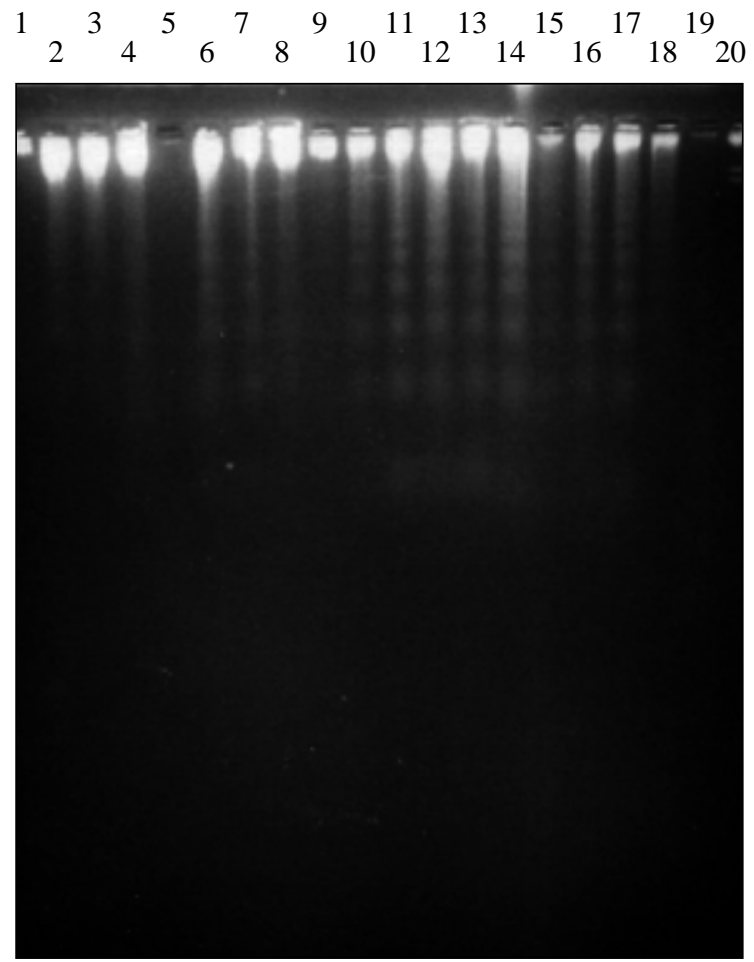

Fig. 3. LM-PCR: DNA fragmentation in leukocytes from four cultivated groups in given time intervals obtained by LM-PCR. DNA was isolated from leukocytes taken from four groups A control, B - group with MSHP, C - group with killed bacteria, D group with living bacteria, in three time intervals 1,4 and $8 \mathrm{~h}$ after phagocytosis beginning. Runs: - 1-A/1h, 2-B/1h, 3-C/1h, 4-D/1h, 5-A/4h, 6-B/4h, 7-C/4h, 8-D/4h, 9-A/8h, 10-B/8h, 11-DNA marker 